\title{
Volunteer Captain Dies After Floor Collapse Traps Him in Basement - New York
}

\section{Executive Summary}

On January 22, 2013, a 34-year-old male volunteer captain (the victim) died when the floor collapsed and trapped him in the basement at a residential structure fire. Crews were attempting to locate and extinguish fire that might have spread from a nearby shed fire that they were dispatched to. While a crew was fighting fire that had spread into the basement, the victim and his partner where pulling the ceiling just inside the front door to extinguish the fire that had spread to the attic. The floor collapsed sending them both into the basement. The victim's partner was able to make it back up to the first floor doorway. He attempted to assist the victim out of the basement, but was unable to pull him up. The hole that the fire fighter had fallen through became

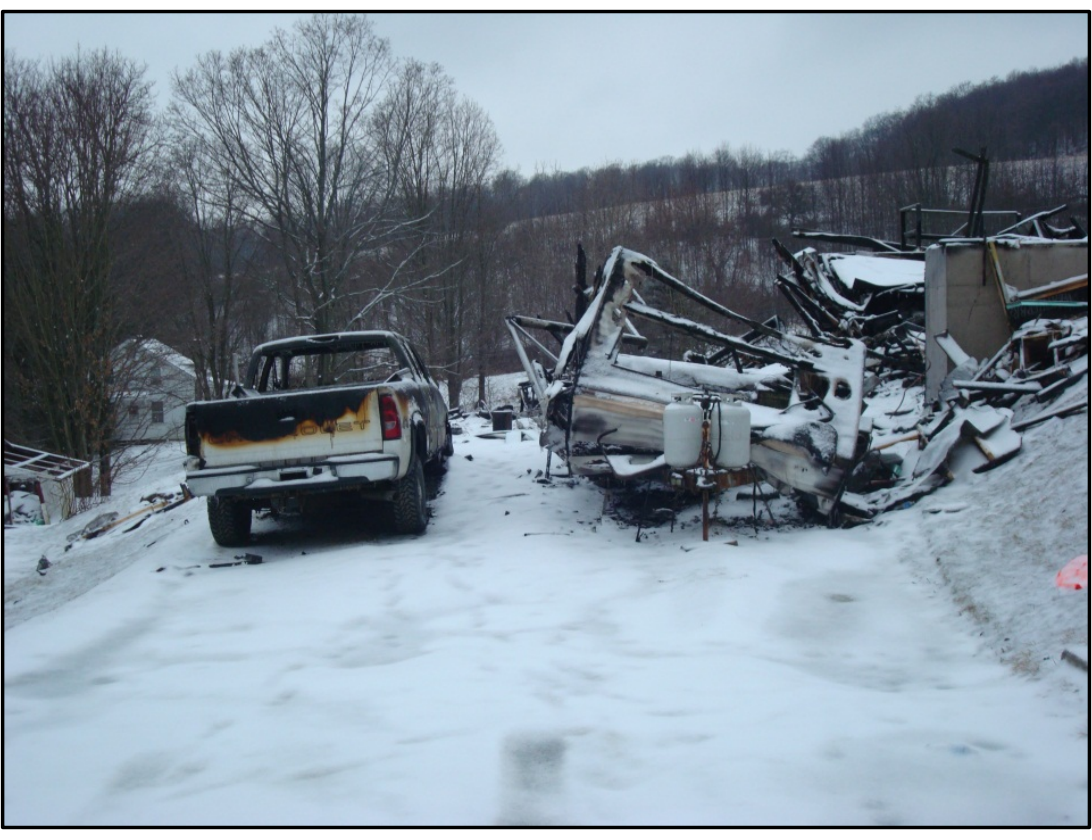

Shed fire location in front of camper and truck which spread to house. (NIOSH Photo) untenable due to the fire conditions and fire fighters were unable to rescue him from the basement. The victim was recovered from the basement approximately 20 minutes later. Before he could be rescued, the victim's mask became thermally degraded and he was overcome by the products of combustion. He was transported to a local hospital where he was pronounced dead.

\section{Contributing Factors}

- Inadequate water supply

- Ineffective fireground communications

- Ineffective incident command

- Inadequate size-up

- Uncoordinated fire attack 


\section{Volunteer Captain Dies After Floor Collapse Traps Him in Basement - New York}

- Lack of situational awareness

- Deteriorated structural members

\section{Key Recommendations}

- Fire departments should develop, implement and enforce a written Incident Management System to be followed at all emergency incident operations

- Fire departments should ensure that the Incident Commander conducts an initial 360-degree size-up and risk assessment of the incident scene before beginning interior fire fighting operations

- Fire departments should ensure that an adequate water supply is established and maintained

- Fire departments should train fire fighters to communicate interior and exterior conditions to the incident commander as soon as possible and to provide regular updates.

The National Institute for Occupational Safety and Health (NIOSH), an institute within the Centers for Disease Control and Prevention (CDC), is the federal agency responsible for conducting research and making recommendations for the prevention of work-related injury and illness. In 1998, Congress appropriated funds to NIOSH to conduct a fire fighter initiative that resulted in the NIOSH "Fire Fighter Fatality Investigation and Prevention Program" which examines line-of-duty-deaths or on duty deaths of fire fighters to assist fire departments, fire fighters, the fire service and others to prevent similar fire fighter deaths in the future. The agency does not enforce compliance with State or Federal occupational safety and health standards and does not determine fault or assign blame. Participation of fire departments and individuals in NIOSH investigations is voluntary. Under its program, NIOSH investigators interview persons with knowledge of the incident who agree to be interviewed and review available records to develop a description of the conditions and circumstances leading to the death(s). Interviewees are not asked to sign sworn statements and interviews are not recorded. The agency's reports do not name the victim, the fire department or those interviewed. The NIOSH report's summary of the conditions and circumstances surrounding the fatality is intended to provide context to the agency's recommendations and is not intended to be definitive for purposes of determining any claim or benefit..

For further information, visit the program website at www.cdc.gov/niosh/fire or call toll free 1-800-CDC-INFO (1-800-232-4636). 


\section{Volunteer Captain Dies After Floor Collapse Traps Him in Basement - New York}

\section{Introduction}

On January 22, 2013, a 34-year-old male volunteer captain (the victim) died when the floor collapsed and trapped him in the basement of a residential structure fire. On January 22, 2013, the U.S. Fire Administration notified the National Institute for Occupational Safety and Health (NIOSH) of this incident. On January 28-31, 2013, two safety and occupational health specialists and a general engineer from the NIOSH Fire Fighter Fatality Investigation and Prevention Program traveled to New York to investigate this incident. The NIOSH investigators met with the victim's fire department, the volunteer department who commanded the incident, volunteer departments who responded to the incident, the county coroner's office, and the state fire marshal's office. Interviews were conducted with fire fighters from the various departments who were on scene during this incident. The incident scene was visited and photographed. NIOSH investigators also reviewed the victim's training records, the incident commander's training records and both the victim's department and the incident commander's department standard operating procedures.

\section{Fire Department}

This volunteer fire department has 1 station with over 30 active members who serve a population of approximately 5,200 within an area of about 60 square miles.

\section{Training and Experience}

\section{Incident Command}

The Incident Commander (IC) had more than 25 years of experience and training on topics including incident command system, water supply operations, initial fire attack, fire fighter survival, firefighting essentials and firefighter assist and search team.

\section{$\underline{\text { Victim }}$}

The victim had more than 18 years of experience and training on topics including introduction to incident command system, hose operations, self-contained breathing apparatus and personal protective equipment, pump operations, and fire protection and organization.

\section{Personal Protective Equipment}

At the time of the incident, each fire fighter entering the structure was wearing a full ensemble of personal protective clothing and equipment, consisting of turnout coats and pants, Nomex ${ }^{\circledR}$ hood, helmet, gloves, boots, and a self-contained breathing apparatus (SCBA) with an integrated PASS device. 


\section{Volunteer Captain Dies After Floor Collapse Traps Him in Basement - New York}

The victim's SCBA was a different brand than the IC's department. The victim's SCBA also had a 45minute rated air cylinder. The incident commander's department used a smaller 30-minute air cylinder.

The IC's department SCBA, air cascade, and rapid intervention equipment were not compatible with the victim's SCBA equipment. The IC's department had a high pressure cylinder 4500 psi and the victim's department had a low pressure cylinder 2216 psi. They would not have been able to transfill at the scene if needed.

\section{Water Supply}

The incident occurred in a rural setting where city water and hydrants were not available. Water supply was provided by mutual aid tankers. They shuttled water from a nearby pond approximately $1 / 4$ mile away from the structure fire. The water was off-loaded into a portable 2,000 gallon tank set up in front of the house in the ditch between the yard and the steeply inclined roadway.

\section{Structure}

The residential structure involved in this incident was built in the 1974 and was a single story, ranchstyle house made of wood frame construction with exterior aluminum siding. It was a three bedroom home with approximately 1,288 square feet of living space. It had a full basement that was below grade on Side-A and Side-D. Side-B had a garage door and Side-C had a man door and a sliding glass door. The gable roof system was constructed with 2 x 4 wooden trusses and contained an attic space. The roof was covered with plywood and asphalt shingles.

During the NIOSH investigation, it was noted that modifications to the structural components in the basement had been made by the owner to complete a remodeling project in 1990. The project turned the garage space in the basement into a hobby shop and office for gunsmith operations. The office was located in the $\mathrm{B} / \mathrm{C}$ corner of the basement. It had an entrance through a man door on Side $\mathrm{C}$ and was partitioned from the rest of the basement with walls constructed with $2 x 4$ studs and drywall. Most of the gunsmith supplies and ammunition were in the A/B corner of the basement. The flooring components near the front of the house showed signs of rot and insect damage.

\section{Investigation}

On January 22, 2013, at 2245 hours, central dispatch received a call for a shed fire. The fire chief (IC) was the first to arrive on the scene and reported a working house fire. He then requested tankers from two mutual aid departments. He approached the homeowner who informed him that there was a large supply of various types of ammunition in the basement. Engine 601was the first apparatus to arrive on scene with two assistant chiefs, two lieutenants, and the driver operator. When they arrived on scene, flames had spread from the shed to a camper just in front of the shed, and the house approximately 15 feet to the north east of the shed. The entire Side B of the house was engulfed by fire when Engine 601 arrived. 


\section{Volunteer Captain Dies After Floor Collapse Traps Him in Basement - New York}

A lieutenant (LT1) and assistant chief deployed a 1 3/4-inch 150-foot pre-connect handline to the front door of the structure. A lieutenant and assistant chief deployed a $13 / 4$-inch 200-foot pre-connect handline to the front of the camper to attempt to extinguish the fire and protect the two external propane tanks on the camper. During this time, a fire fighter from the IC's department arrived and assumed the role of incident safety officer (ISO). He attempted to obtain all of the accountability tags from all the fire fighters on scene, but he was needed to run equipment to support the fire fighting efforts.

At the front door, the crew encountered smoke coming out of the entire height of the door. Inside there was zero visibility with minimal heat. They conducted a left hand search of the house searching for fire. They did not find any fire inside on the first floor and started to exit the structure.

At this time the victim was arriving on scene with a lieutenant (LT2) and a driver/operator in the requested 2,000 gallon mutual aid tanker. They had attempted to contact the incident commander for instructions multiple times while in route to the scene and several times for instructions when they reached the fireground without any response from the IC. They had tried contacting the IC on both of their radio frequencies. Note: The two departments had incompatible radio frequencies and could not communicate directly. The tanker had to stop on the road to the structure due to another tanker offloading water in the portable tank in front of the structure. LT2 walked up to the IC for orders and informed him he had another "Green Tag" fire fighter with him. Note: "Green Tag" refers to fire fighters who are certified to fight interior fires in this region. LT2 went back to the tanker to get the victim to deploy a handline and make an interior attack. The victim, who had a radio, asked LT2 if he had one, which he did not. They deployed another 1 3/4-inch handline off of Engine 601 and proceeded to the front door.

LT1 and the assistant chief were just inside the front door at this time. There was some visible fire at the ceiling that they were knocking down. LT2 saw the fire and returned to get a pike pole to pull the ceiling to search for and extinguish any hidden fire. The assistant chief and LT1 exited the front door and pulled their handline around Side D to Side C searching for fire extension. They found a sliding glass door on Side C, near the C/D corner and broke it out to gain access into the basement.

The victim and LT2 made entry at the front door. The victim was pulling the ceiling while LT2 was operating the nozzle. They observed fire running in the attic towards Side D. They were able to knock the fire in the attic down and the visibility improved.

During this time, the assistant chief was inside the basement going down a hallway toward Side B. LT1 was outside pulling hose around to the sliding glass door. The conditions inside the basement were light smoke with moderate heat. There was a door to the outside on Side $\mathrm{C}$ closer to the B/C corner. The Assistant Chief opened it. He noticed light to medium fire conditions in the B/C corner of the basement through a window in an interior wall when he opened the door. Note: In the B/C corner of the basement, the owner had an office set up for his gunsmith business that he separated from the rest of the basement with walls. Most of the gunsmith supplies were in the A/B corner of the basement. 


\section{Volunteer Captain Dies After Floor Collapse Traps Him in Basement - New York}

LT1 entered the basement with the assistant chief and they both advanced the hoseline down the basement to the wall to the office. They ran out of water a couple times while attempting to fight the fire. Both members ran out of air and exited to get another air pack. The conditions were much hotter as they made their way back inside to the nozzle. They were calling for additional hose because their handline was too short to advance to the B/C corner. They had an interior tool with them and decided to open the wall toward Side A in the hallway. When they opened the wall, they could see that the entire Side A of the basement was fully involved. LT1 told the assistant chief that the first floor was shaking. The assistant chief transmitted that the first floor was failing. Note: This transmission was not heard nor received by any members on the fireground. He sent LT1 outside to tell the IC to transmit the evacuation tones.

At Side A the victim and LT2 were fighting fire in the attic when the heat intensified and visibility went to zero. LT2 laid the nozzle down and moved a couple of feet straight ahead into a hallway. He looked toward Side C and Side D expecting to see heavy fire. He returned to the front door with the victim. Side B was fully involved at this time. The victim was using a pike pole to pull the ceiling and LT2 was flowing water from Side B to Side C when the floor collapsed and they fell into the basement.

LT2 landed on his hands and knees in the basement that was fully engulfed in fire. He could see his face shield melting and heard the nozzle bouncing around on the first floor above him. The victim was calling a Mayday. LT2 found a piece of furniture leaning up where it had fallen into the basement. He yelled for the victim to follow him and climb up the piece of furniture. The victim tugged on his coat. LT2 reached back for the victim who grabbed his hand and he yelled for the victim to follow him as he climbed up the furniture to the first floor. When he got up on the first floor he had lost his mask and helmet and the air horns were sounding. He looked for the victim but he was not on the first floor. He looked back down through the hole he had just climbed up and all he could see was fire. He yelled for the victim to give him his hands which he did immediately. He was attempting to pull him up and got hold of the left strap of his air pack. LT2 was yelling for him to fight and yelling outside of the door for help. One other fire fighter and a civilian responded to LT2's calls for help and tried to pull up the victim who was talking and responsive. Then the victim went limp. The three continued to try to pull the victim out of the basement when the floor started to collapse more and they were forced to release their hold of the victim and back out from the front door.

Fire fighters immediately went to the garage entrance of Side B and continued their rescue efforts. The victim was removed from the basement within 20 minutes and transported to a local hospital where he was pronounced dead.

\section{Fire Behavior}

According to the state fire marshal's office, the fire originated in a shed approximately 15 feet away from the $\mathrm{B} / \mathrm{C}$ corner of the house. The fire spread to a camper just in front of the shed and then to the house adjacent to the camper.

While crews searched for fire extension on the first floor, the fire entered the basement through the garage door area. The fire continued to develop inside the house and went unnoticed. A crew advanced a handline around the D/C Side of the basement and made entry through a sliding glass door 


\section{Volunteer Captain Dies After Floor Collapse Traps Him in Basement - New York}

on Side C. The basement was sectioned off to separate the gunsmith business from the rest of the house and the developing fire went unnoticed as the crew struggled with water issues and not enough hose to find and fight the fire.

The fire eventually compromised the structural integrity of the flooring system and the first floor collapsed trapping the victim in the basement.

\section{Contributing Factors}

Occupational injuries and fatalities are often the result of one or more contributing factors or key events in a larger sequence of events that ultimately result in the injury or fatality. NIOSH investigators identified the following items as key contributing factors in this incident that ultimately led to the fatalities:

- Inadequate water supply

- Ineffective fireground communications

- Ineffective incident command

- Inadequate Size-up

- Lack of situational awareness

- Uncoordinated fire attack

- Deteriorated structural members.

\section{Cause of Death}

According to the death certificate, the medical examiner listed the victim's cause of death as due to acute thermal inhalation injury, with cardiac arrhythmia and thermal hypoxia. The mechanism of death may have been laryngeal spasm related to acute thermal inhalation injury.

\section{Recommendations}

\section{Recommendation \#1: Fire departments should develop, implement and enforce a written Incident Management System to be followed at all emergency incident operations.}

Discussion: National Fire Protection Association (NFPA) 1500 Standard on Fire Department Occupational Safety and Health Program, 2013 Edition, ${ }^{-}$and NFPA 1561 Standard on Emergency Services Incident Management System, 2008 Edition, ${ }^{-}$both state that an Incident Management System (IMS) should be utilized at all emergency incidents (including but not limited to training exercises). The U.S. Department of Labor, Occupational Safety and Health Administration has issued a guidance document intended to be used by agencies to prepare emergency response plans. The intent of the National Response Team (NRT) guidance is to provide a mechanism for consolidating multiple agencies’ plans into one functional emergency response plan or integrated contingency plan (ICP). ${ }^{3}$ 


\section{Volunteer Captain Dies After Floor Collapse Traps Him in Basement - New York}

NFPA 1561, Chapter 3.3.29 defines the Incident Management System (also known as the Incident Command System (or ICS) as "A system that defines the roles and responsibilities to be assumed by responders and the standard operating procedures to be used in the management and direction of emergency incidents and other functions. ${ }^{2}$ Chapter 4.1 states "The incident management system shall provide structure and coordination to the management of emergency incident operations to provide for the safety and health of emergency services organization (ESO) responders and other persons involved in those activities." Chapter 4.2 states "The incident management system shall integrate risk management into the regular functions of incident command.” Each fire department or emergency services organization (ESO) should adopt an incident management system to manage all emergency incidents. The IMS should be defined and in writing and include standard operating procedure (SOPs) covering the implementation of the IMS. The IMS should include written plans that address the requirements of different types of incidents that can be anticipated in each fire department's or ESO's jurisdiction. The IMS should address both routine and unusual incidents of differing types, sizes and complexities. The IMS covers more than just fireground operations. The IMS must cover incident command, accountability, risk management, communications, rapid intervention teams (RIT), roles and responsibilities of the Incident Safety Officer (ISO), and inter-operability with multiple agencies (police, emergency medical services, state and federal government, etc.) and surrounding jurisdictions (mutual aid responders).

NIOSH investigators identified several instances in this incident in which recognized guidelines for IMS were not followed. Specific examples include multiple chief officers serving in command roles in an uncoordinated manner, lack of an established accountability system to track fire fighters on scene, and a RIT was not established.

\section{Recommendation \#2: Fire departments should ensure that the Incident Commander conducts an initial size-up and risk assessment of the incident scene to asses if an interior attack is warranted before beginning interior fire fighting operations.}

Discussion: Among the most important duties of the first officer on the scene is conducting an initial size-up of the incident. This information lays the foundation for the entire operation. It determines the number of fire fighters and the amount of apparatus and equipment needed to control the blaze, assists in determining the most effective point of fire extinguishment attack, the most effective method of venting heat and smoke, and whether the attack should be offensive or defensive. A proper size-up begins from the moment the alarm is received and it continues until the fire is under control. The sizeup should also include assessments of risk versus gain during incident operations. ${ }^{4-9}$ Retired Chief Alan Brunacini recommends that the arriving IC drive partially or completely around the structure whenever possible to get a complete view of the structure. While this may delay the IC's arrival by a few seconds, this drive-by may provide significant details not visible from the command post. ${ }^{-}$The size-up should include an evaluation of factors such as the fire size and location, length of time the fire has been burning, conditions on arrival, occupancy, fuel load and presence of combustible or hazardous materials, exposures, time of day, and weather conditions. Information on the structure itself including size, construction type, age, condition (evidence of deterioration, weathering, etc.), evidence of renovations, lightweight construction, loads on roof and walls (air conditioning units, ventilation 


\section{Volunteer Captain Dies After Floor Collapse Traps Him in Basement - New York}

ductwork, utility entrances, etc.), and available pre-plan information are all key information which can effect whether an offensive or defensive strategy is employed. The size-up and risk assessment should continue throughout the incident.

Interior size-up is just as important as exterior size-up. Since the IC is staged at the command post (outside), the interior conditions should be communicated to the IC as soon as possible. Interior conditions could change the IC's strategy or tactics. For example, if heavy smoke is emitting from the exterior roof system, but fire fighters cannot find any fire in the interior, it is a good possibility that the fire is above them in the roof system. Other warning signs that should be relayed to the IC include dense black smoke, turbulent smoke, smoke puffing around doorframes, discolored glass, and a reverse flow of smoke back inside the building. It is important for the IC to immediately obtain this type of information to help make the proper decisions. Departments should ensure that the first officer or fire fighter inside the structure evaluates interior conditions and reports them immediately to the IC.

In this incident, arriving officers concentrated on the A and B-sides of the structure near the shed and camper fires. A complete 360 degree size-up was never conducted. Initial interior attack was on the first floor. As the crews concentrated their efforts to search for fire on the first floor, the fire spread into the basement through the garage door windows on Side-B which was within 10 feet of the camper.

\section{Recommendation \#3: Fire departments should develop and coordinate pre-incident planning protocols with mutual aid departments.}

Discussion: NFPA 1620 provides guidance to assist departments in establishing pre-incident plans. Pre-incident planning that includes agreements formed by a coalition of all involved parties including mutual aid fire departments, emergency medical services companies, and police, will present a coordinated response to emergency situations, and may save valuable time by a more rapid implementation of pre-determined protocols. ${ }^{10}$ Mutual aid companies should train together and not wait until an incident occurs to attempt to integrate the participating departments into a functional team. Differences in equipment and procedures need to be identified and resolved before an emergency occurs where lives may be at stake. Procedures and protocols that are jointly developed, and have the support of the majority of participating departments, will greatly enhance overall safety and efficiency on the fireground. Once methods and procedures are agreed upon, training protocols must be developed and joint-training sessions conducted to relay appropriate information to all affected department members.

Examples of such pre-incident planning for this incident would include use of compatible air packs with the same cylinder pressures, compatible communication equipment with the same channels, coordinated water shuttle operation, coordinated incident command and tactical operations, and incident scene safety. 


\section{Volunteer Captain Dies After Floor Collapse Traps Him in Basement - New York}

\section{Recommendation \#4: Fire departments should ensure the early implementation of division and group command into the Incident Command System.}

Discussion: The early establishment of divisions and groups allows the command structure of an incident to grow more effectively than simply deploying resources and assigning division or group supervisors after units are in place. Delegating division / group command to other officers makes the management of a large incident more feasible by relieving the Incident Commander of these responsibilities which allows the IC to focus on the bigger picture while still maintaining the ability to react to progress reports and other information provided by the division / group commanders. The Model Procedures Guide for Structural Firefighting describes the application of the National Fire Service Incident Management System (NIMS) to structure fire incidents. These procedures recommend the establishment of division and group command. $1 \underline{11}$

In this incident, a strategy of coordinated division and group command was not employed, including water shuttle operations. There was not any clear communications as to the volume of fire in the basement or the request to evacuate the structure from the interior crew in the basement. The interior crews operating on the first floor did not know of the extent of fire below them in the basement.

\section{Recommendation \#5: Fire departments should ensure that an adequate water supply is established and maintained.}

Discussion: Establishing adequate water supply on the fireground is one of the most critical elements of firefighting. It is important in areas with a water distribution system and even more critical in areas where water must be supplied. ${ }^{12,13}$ The objective of an offensive fire attack is to apply enough water directly to the burning fuel to achieve extinguishment. ${ }^{14}$ Rural or underdeveloped areas typically rely on tender-based water supply operations. Tender operations involve transporting large quantities of water between a fill site and the fireground. Once on the fireground, water is typically off-loaded to a portable tank so that an engine can use a suction hose to draft and supply water to attack the fire. $\frac{12}{}$

Suppression operations at this incident were delayed due to fact that the department in command could not communicate to the initial arriving tanker companies. Arriving tankers could not get the information where the fill site was located, and an officer was not designated to oversee the water shuttle operation. The portable tank was set up on a hillside in a ditch in front of the house. The tankers had to turn around just below the fireground and back up the hill to offload their water. The tankers could not off-load their entire tank due to the portable tank being off-balance and to the steep incline.

Ideally, the tankers could have off-loaded their water just below the fireground where the road was flat. An engine could have pumped from the tank up the hill to supply another engine. Departments should also regularly practice water shuttle operations to ensure that their members are well versed in utilizing the equipment and apparatus to provide adequate water flow for anticipated fire situations. ${ }^{12,15-16}$ 


\section{Volunteer Captain Dies After Floor Collapse Traps Him in Basement - New York}

\section{Recommendation \#6: Fire departments should train fire fighters to communicate interior and exterior conditions to the incident commander as soon as possible and to provide regular updates.}

Discussion: Proper size-up and risk versus gain analysis requires that the incident commander have a number of key pieces of information and keep informed of the constantly changing conditions on the fireground. New decisions must be made and old ones revised based upon new data and improved information. Decisions can be no better than the information on which they are based. The IC must use an evaluation system that considers and accounts for changing fireground conditions in order to stay ahead of the fire. If this is not done, the attack plan will be out of sequence with the phase of the fire and the IC will be constantly surprised by changing conditions. ${ }^{1,2,7,8}$ Interior size-up is just as important as exterior size-up. Since the IC is staged at the command post (outside), the interior conditions should be communicated by interior crews as soon as possible to the IC. Interior conditions could change the IC's strategy or tactics. Interior crews can aid the IC in this process by providing reports of the interior conditions as soon as they enter the fire building and by providing regular updates.

In this incident, the IC was not advised of the heavy fire load in the basement and that crews were operating above the fire on the first floor.

\section{Recommendation \#7: Fire departments should ensure that a separate Incident Safety Officer, independent from the Incident Commander, is appointed at each structure fire.}

Discussion: According to NFPA 1561 Standard on Emergency Services Incident Management System, 2014 Edition, paragraph 5.3, "The Incident Commander shall have overall authority for management of the incident (5.3.1) and the Incident Commander shall ensure that adequate safety measures are in place (5.3.2)." This shall include overall responsibility for the safety and health of all personnel and for other persons operating within the incident management system. While the Incident Commander (IC) is in overall command at the scene, certain functions must be delegated to ensure adequate scene

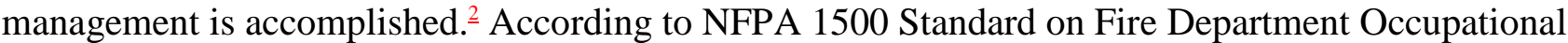
Safety and Health Program, 2013 Edition, "as incidents escalate in size and complexity, the Incident Commander shall divide the incident into tactical-level management units and assign an incident safety officer (ISO) to assess the incident scene for hazards or potential hazards (8.1.6)." ${ }^{11}$ These standards indicate that the IC is in overall command at the scene, but acknowledge that oversight of all operations is difficult. On-scene fire fighter health and safety is best preserved by delegating the function of safety and health oversight to the ISO. Additionally, the IC relies upon fire fighters and the ISO to relay feedback on fireground conditions in order to make timely, informed decisions regarding risk versus gain and offensive versus defensive operations. The safety of all personnel on the fireground is directly impacted by clear, concise, and timely communications among mutual aid fire departments, sector command, the ISO, and IC.

Chapter 6 of NFPA 1521, Standard for Fire Department Safety Officer, defines the role of the ISO at an incident scene and identifies duties such as: recon of the fireground and reporting pertinent information back to the Incident Commander; ensuring the department's accountability system is in place and operational; monitoring radio transmissions and identifying barriers to effective communications; and ensuring established safety zones, collapse zones, hot zones, and other 


\section{Volunteer Captain Dies After Floor Collapse Traps Him in Basement - New York}

designated hazard areas are communicated to all members on scene. ${ }^{17}$ Larger fire departments may assign one or more full-time staff officers as safety officers who respond to working fires. In smaller departments, every officer should be prepared to function as the ISO when assigned by the IC. The presence of a safety officer does not diminish the responsibility of individual fire fighters and fire officers for safety. The ISO adds a higher level of attention and expertise to help the fire fighters and fire officers. The ISO must have particular expertise in analyzing safety hazards and must know the particular uses and limitations of protective equipment.

In this incident, an ISO was designated but was assisting crews and the IC with equipment rather than monitoring the fireground for hazards.

Recommendation \#8: Fire departments should ensure that fire fighters and officers understand the capabilities and limitations of thermal imaging cameras (TIC) and that a TIC is used as part of the size-up process.

Discussion: Thermal imaging cameras (TICs) can be a useful tool for initial size-up and for locating the seat of a fire. Infrared thermal cameras can assist fire fighters in quickly getting crucial information about the location of the source (seat) of the fire from the exterior of the structure, which can help the incident command plan an effective and rapid response. Knowing the location of the most dangerous and hottest part of the fire may help fire fighters determine a safer approach and avoid exposure to structural damage in a building that might have otherwise been undetectable. While TICs provide useful information to aid in locating the seat of a fire, they cannot be relied upon to assess the strength or safety of floors and ceilings. ${ }^{14}$ TICs should be used in a timely manner, and fire fighters should be properly trained in their use and be aware of their limitations. $\frac{18,19}{1}$ While use of a TIC is important, research by Underwriters Laboratories has shown that there are significant limitations in the ability of these devices to detect temperature differences behind structural materials, such as the exterior finish of a building or outside compartment linings (walls, ceilings, and floors). ${ }^{20}$ Fire fighters and officers should be wary of relying on this technology alone and must integrate this data with other fire-behavior indicators to determine potential fire conditions. TICs may not provide adequate size-up information in all cases, but using one is preferred to not using one.

During this incident, the victim and his partner started a search without an assignment or briefing on the scene or building. Unknown to the victim and his partner, they ended up searching above the fire. A TIC may have shown them that the fire was below them in the basement and had not yet extended into the first floor when they made initial entry.

\section{Recommendation \# 9: Fire departments should provide all fire fighters with radios and train them on their proper use.}

Discussion: In September 2003, NIOSH released the document, Current Status, Knowledge Gaps, and Research Needs Pertaining to Firefighter Radio Communication Systems. $\stackrel{21}{\text { Page } 13}$ states: "It is critical for firefighters to communicate with one another within a structure and with units operating outside the structure, regardless of the building construction." The best 


\section{Volunteer Captain Dies After Floor Collapse Traps Him in Basement - New York}

way this can be done when crews are separated or in trouble is through the use of a personal portable radio.

National Fire Protection Association (NFPA) 1561, Standard on Emergency Services Incident Management System, Section 6.3 Emergency Traffic, states in section 6.3.1: "To enable responders to be notified of an emergency condition or situation when they are assigned to an area designated as immediately dangerous to life or health (IDLH), at least one responder on each crew or company shall be equipped with a portable radio and each responder on the crew or company shall be equipped with either a portable radio or another means of electronic communication."르 The joint U.S. Fire Administration (USFA) and International Association of Fire Fighters (IAFF) report, Voice Radio Communications Guide for the Fire Service, ${ }^{22}$ provides an overview of radio communication issues involving the fire service. Effective fireground radio communication is an important tool to ensure fireground command and control as well as helping to enhance fire fighter safety and health. Every fire fighter on the fireground should be provided with their own radio in case they become lost or separated from their crew. It is every fire fighter's and company officer's responsibility to ensure radios are properly used. Ensuring appropriate radio use involves both taking personal responsibility (to have your radio, having it on, and on the correct channel) and a crew based responsibility to ensure that the other members of your crew are doing so as well. Radios should be designed and positioned to allow the fire fighter to monitor and transmit a clear message. These radios should be well maintained and inspected by qualified personnel on a regular basis.

Both the International Association of Fire Chiefs (IAFC) ${ }^{23}$ and the International Association of Fire Fighters (IAFF) $)^{22}$ recommend that all fire fighters be assigned a radio. In 1999, the U.S. Fire Administration technical report Improving Firefighter Communications identified a number of radio communication issues, including the need for all fire fighters to have portable radios. The report stated "Ideally, every firefighter working in a hostile environment should have a portable radio with emergency distress feature."24 The IAFF Fireground Survival Program contains training on radio communication procedures in emergency operations including how to call a Mayday. ${ }^{25}$

In this incident the victim's partner did not have a radio with him which prevented him from radioing for assistance. Additionally, he would have only been able to talk to members from his own department due to the two departments having incompatible radio frequencies.

\section{Recommendation \#10: Fire departments should ensure that fire fighters are trained in situational awareness, personal safety, and accountability.}

Discussion: The ability to maintain situational awareness is reliant on a fire fighter's training, a fire fighter's judgment and a fire fighter's personal condition. These factors must come together every time a fire fighter goes to an emergency incident especially those involving a low-frequency, high risk event such as structural fire-fighting, wildland fire-fighting, trench rescue, high angle rescue, or any of the wide arrays of emergencies fire fighters are called upon to mitigate. A lack of competency, or even a temporary lack of focus, can lead to a chain of events that may be catastrophic or even fatal.

To properly train our personnel to maintain situational awareness on the fireground or at any emergency incident, a fire department has to develop and utilize effective scenario based training. 


\section{Volunteer Captain Dies After Floor Collapse Traps Him in Basement - New York}

Training fire fighters to maintain situational awareness on the fireground needs to include building construction, fire behavior, fireground tactics and strategy, ventilation, and other fireground operations. This is a continuous process that is initiated in recruit school and continues through a fire fighter's entire fire service career. $\underline{26}$

Fire fighters need to understand the importance of situational awareness, personal safety, and company/crew accountability on the fireground. The fireground dangers and hazards can and do change as an incident evolves and the event duration increases. Situational awareness is defined as recognition of the immediate surroundings. On the fireground, every fire fighter should be trained to be constantly alert for changing and unsafe conditions related to their immediate surroundings. This applies not only to the conditions found within a burning structure, but to the exterior fireground as well. $\stackrel{4}{ }$

The company officer is the key focus of this process to ensure that the fire fighters under his/her direction are properly trained to maintain situational awareness at every incident scene. The company officer needs to ensure that situational awareness training has to occur during company drills, classroom training, and during live fire training. Another opportunity to enhance situational awareness is through critiques or a formal post incident analysis. This gives a company officer and crew a formal or informal method of learning from an incident whether fireground or operations went well or improvements need to be made. ${ }^{1}$

There are many issues that can create barriers or boundaries that effect situational awareness. These barriers or boundaries include but are not limited to:

- Lack of proper training;

- Lack of effective scene size-up;

- Task fixation or tunnel vision;

- Task overload;

- $\quad$ Lack of or failure to follow the Incident Commander's Incident Action Plan (tactics);

- Lack of effective fireground communications; $; 7$

Fire fighters can maintain their situational awareness by looking up, down, and around as well as listening for new or unusual sounds and feeling vibrations or movement. Fire fighters and officers should communicate any changes in their environment to other members as well as to the Incident Commander.

Recommendation \#11: Fire departments should ensure that fire fighters are properly trained in Mayday standard operating guidelines and survival techniques.

Discussion: Fire fighters need to maintain situational awareness at all times while operating on the fireground. Fire fighters need to understand that their personal protective equipment (PPE) and selfcontained breathing apparatus (SCBA) do not provide unlimited protection. Fire fighters should be trained to stay low when advancing into a fire as extreme temperature differences may occur between the ceiling and floor. When confronted with an emergency situation, the best action to take may be 


\section{Volunteer Captain Dies After Floor Collapse Traps Him in Basement - New York}

immediate egress from the building or to a place of safe refuge (e.g., behind a closed door in an uninvolved compartment, in a staging area on a lower floor) and manually activate the PASS device. A charged hoseline should always be available for a tactical withdrawal while continuing water application or as a lifeline to be followed to egress the building. Conditions can become untenable in a matter of seconds. Fire fighters must understand that when they are faced with a life-threatening emergency, there is a very narrow window of survivability, and any delay in egress and/or to transmission of a Mayday message reduces the chance for a successful rescue. Knowledge and skill training on preventing a Mayday situation or how to call a Mayday should be mastered before a fire fighter engages in fireground activities or other immediately dangerous to life and health (IDLH) environments. ${ }^{28}$ Fire fighter training programs should include training on such topics as air management; familiarity with SCBA, a radio, and PPE; crew integrity; reading smoke, fire dynamics and behavior; entanglement hazards; building construction, and signs of pending structural collapse. If fire fighters find themselves in a questionable position (dangerous or not), they must be able to recognize this and be trained on procedures for when and how a Mayday should be called. A fire fighter's knowledge, skill, and ability to declare a Mayday must be at the mastery level of performance. This performance level should be maintained throughout their career through training offered more frequently then annually. $\cdot \underline{-9}$

The ability of a fire fighter to call a Mayday is a complicated behavior that includes the affective, cognitive, and psychomotor domains of learning and performance. ${ }^{30,31}$ Any delay in calling a Mayday reduces the chance of survival and increases the risk to other fire fighters trying to rescue the downed fire fighter.

Firefighters should be 100\% confident in their competency to declare a Mayday for themselves. Fire departments should ensure that any personnel who may enter an IDLH environment meet the Authority Having Jurisdiction standards for Mayday competency throughout their active duty service. Presently there are no national Mayday standards for firefighters to be trained to and most states do not have Mayday standards. A rapid intervention team (RIT) will typically not be activated until a Mayday is declared. Any delay in calling the Mayday reduces the window of survivability and also increases the risk to the RIT.

There are no rules on when a fire fighter must call a Mayday, and Mayday training is not included in the job performance requirements in NFPA Fire Fighter 1 or 2 standards. ${ }^{1}$ It is up to each authority having jurisdiction to develop rules and performance standards for a fire fighter to call a Mayday. The National Fire Academy Mayday courses present specific Mayday parameters or rules for when a fire fighter must call a Mayday. The courses may help fire departments in developing and teaching Mayday procedures for fire fighters.

The National Fire Academy has two courses addressing the fire fighter Mayday Doctrine, Q133 Firefighter Safety: Calling the Mayday, which is a 2-hour program covering the cognitive and affective learning domain of the fire fighter Mayday Doctrine, and H134 Calling the Mayday: Hands-on Training, which is an 8-hour course that covers the psychomotor learning domain of the fire fighter Mayday Doctrine. These courses are based on the military methodology used to develop and teach 


\section{Volunteer Captain Dies After Floor Collapse Traps Him in Basement - New York}

fighter pilots ejection doctrine. A training CD is available to fire departments free of charge from the U.S. Fire Administration Publications office. $\stackrel{31,32}{ }$

Also, the IAFF Fire Ground Survival program is another resource fire departments can use and was developed to ensure that training for Mayday prevention and Mayday operations are consistent between all fire fighters, company officers, and chief officers..$^{25}$

Any Mayday communication must contain the location of the firefighter in as much detail as possible and, at a minimum, should include the division (floor) and quadrant. It is imperative that firefighters know their location when in IDLH environments at all times to effectively be able to give their location in the event of a Mayday. Once in distress, firefighters must immediately declare a Mayday. The following example uses LUNAR (Location, Unit, Name, Assignment/Air, Resources needed) as a prompt: "Mayday, Mayday, Mayday, Division 1 Quadrant C, Engine 71, Smith, search/out of air/vomited, can't find exit." When in trouble, a firefighter's first action must be to declare the Mayday as accurately as possible. Once the IC and RIT know the fire fighter's location, the firefighter can then try to fix the problem, such as clearing the nose cup, while the RIT is en route for rescue. ${ }^{32}$

A fire fighter who is breathing carbon monoxide (CO) quickly loses cognitive ability to communicate correctly and can unknowingly move away from an exit, other fire fighters, or safety before becoming unconscious. Without the accurate location of a downed fire fighter, the speed at which the RIT can find them is diminished, and the window of survivability closes quickly because of lack of oxygen and high CO concentrations in an IDLH environment. $\frac{31-33}{3}$

Fire fighters also need to understand the psychological and physiological effects of the extreme level of stress encountered when they become lost, disoriented, injured, run low on air, or become trapped during rapid fire progression. Most fire training curricula do not include discussion of the psychological and physiological effects of extreme stress, such as encountered in an imminently lifethreatening situation, nor do they address key survival skills necessary for effective response. Understanding the psychology and physiology involved is an essential step in developing appropriate responses to life-threatening situations. Reaction to the extreme stress of a life-threatening situation, such as being trapped, can result in sensory distortions and decreased cognitive processing capability. $\cdot{ }^{30}$ In the book Stress and Performance in Diving, the author notes that while all training is important, "We know that under conditions of stress, particularly when rapid problem-solving is crucial, over-learning responses is essential. The properly trained individual should have learned coping behavior so well that responses become virtually automatic requiring less stop and think performance." $\underline{35}$ Fire fighters should never hesitate to declare a Mayday. There is a very narrow window of survivability in a burning, highly toxic building. Any delay declaring a Mayday reduces the chance for a successful rescue. ${ }^{34}$

In this incident, the victim's call for a Mayday was not heard and the victim's partner did not have a radio to make an additional call. 


\section{Volunteer Captain Dies After Floor Collapse Traps Him in Basement - New York}

Recommendation \#12: Fire departments should ensure that a rapid intervention team (RIT) is established and available to immediately respond to emergency rescue incidents.

Discussion: A RIT should be designated and available to respond before interior attack operations begin at all fireground operations. $\frac{2,5,36}{2}$ The team should report to the officer in command and remain in a designated ready position until an intervention is required to rescue a fire fighter(s) or civilians. The RIT should have all tools necessary to complete the task (e.g., a search rope, first-aid kit, and a resuscitator). The RIT's only assignment should be to prepare for a rapid deployment to complete any emergency search or rescue when ordered by the IC. The RIT allows the suppression crews the opportunity to regroup and take a roll call instead of performing rescue operations. A RIT should preplan a rescue operation by finding out fire structure information (i.e., construction materials, layout, entry/egress routes, etc.), crew location and assignments, and monitoring radio traffic. When the RIT enters to perform a search and rescue, they should have full cylinders on their SCBAs and be physically prepared. When a RIT is used in an emergency situation, an additional RIT should be put into place in case an additional emergency situation arises. $\frac{36}{}$ A RIT was not established at this incident.

Recommendation \#13: Fire departments should consider the possibility of a substandard structure when building information is not available from pre-incident plans, and implement a defensive strategy when no occupants are at risk.

Discussion: The threat of a collapse of some type (i.e. roof, ceiling, floor or wall) is a possibility in any structural fire due to the effects of fire, water application, age, insects, and alterations. It is a high probability that a fire department is unaware of structural defects caused by age, insects and alterations. To minimize the risk of injury or death to fire fighters during structural operations, the sizeup and risk assessment includes many factors, which include: age of the building (deterioration of structural members, evidence of weathering, use of lightweight materials in new construction), occupancy, and renovations or modifications to the building. $\frac{1,9,37}{}$

Pre-incident plans are an effective tool in preventing injuries and deaths of fire fighters due to structural collapse. They allow fire departments to determine factors, such as, age of the structure, structural integrity, type of materials used in the structure, and amount of load on the roof that could weaken the supports, etc. However, in numerous cities and towns where buildings number in the hundreds of thousands, fire departments lack the manpower to pre-plan all buildings under their protection. Often fire departments are limited to targeting buildings that have a unique construction or pose a known hazard. Residential structures are typically not pre-planned unless during the construction phase.

"The potential for structural collapse is one of the most difficult factors to predict during initial size-up and ongoing fire fighting. Structural collapse usually occurs without warning." "When pre-incident plan information on the fire structure is not available, occupants have been evacuated, and evidence of structural deterioration and/or modification cannot be determined, a defensive strategy should be implemented. A defensive strategy would help ensure fire fighter safety and is warranted in structures 


\section{Volunteer Captain Dies After Floor Collapse Traps Him in Basement - New York}

that lack pre-incident plans, no occupants are at risk, and where the potential for numerous unrecognized hazards exists, such as substandard construction and building deterioration.

Fire departments operating in older businesses and homes should be suspicious of potential alterations and renovations which could result in unsupported loads and unusual voids. These alterations may be hidden by sheetrock (drywall) or flooring and built up flooring which is difficult to detect during inspections and virtually impossible to detect during firefighting operations. The older the structure, the greater the possibility of renovation or remodel.

In this case, there were no current pre-incident plans for the structure and compromised structural integrity was not immediately evident. The occupants had evacuated upon the fire department's arrival, and no civilian lives were in danger for the structure fire. Structural alterations had been made to the girders, columns, and floor in order to presumably level and support the floor. A post incident inspection showed 2 x 4 boards being used inappropriately (in orientation and stability) as structural support for the main girder used to support the floor joists. The wooden floor members near the front entrance, specifically the header joist and the sill plate showed severe signs of rot and insect damage.

Recommendation \#14: Municipalities should ensure that companies responding to mutual aid incidents are equipped with mobile and portable communications equipment that are capable of handling the volume of radio traffic and allow communications between all responding companies within their jurisdiction.

Units responding to or engaged at incidents should have the necessary radio frequencies/channels to be in contact with other units providing mutual aid. These units should also have the capability to monitor the fireground activities while en-route. ${ }^{38}$ During this incident, many of the units could not communicate with the IC or the local dispatch center on either their portable or mobile radios.

\section{References}

1. NFPA [2013]. NFPA 1500, Standard on fire department occupational safety and health program. 2013 Edition. Quincy, MA: National Fire Protection Association.

2. NFPA [2014]. NFPA 1561 Standard on Emergency Services Incident Management System, 2014 Edition. Quincy, MA: National Fire Protection Association.

3. OSHA [1996]. The National Response Team's Integrated Contingency Plan Guidance; Federal Register Notice 61:28641-28664, June 5, 1996. Posted as a guidance document on the Occupational Health and Safety Administration website http://www.osha.gov/pls/oshaweb/owadisp.show_document?p_table=FEDERAL_REGISTER \&p_id=13550. Date accessed: Aug 2013. 


\section{Volunteer Captain Dies After Floor Collapse Traps Him in Basement - New York}

4. IFSTA [2008]. Essentials of fire fighting, 5th ed. Oklahoma State University. Stillwater, OK: Fire Protection Publications, International Fire Service Training Association.

5. Dunn V [1992]. Safety and Survival on the Fireground. Saddle Brook NJ: Fire Engineering Books and Videos.

6. Dunn V [2000]. Command and Control of Fires and Emergencies. Saddle Brook NJ: Fire Engineering Book and Videos.

7. Brunacini AV [1985]. Fire command. Quincy, MA: National Fire Protection Association.

8. Dunn V [1998]. Risk management and lightweight truss construction. New York: WNYF, Official training publication of the New York City Fire Department, 1st issue.

9. NIOSH [1999]. NIOSH Alert: Request for assistance in preventing injuries and deaths of fire fighters due to structural collapse. Cincinnati, OH: U.S. Department of Health and Human Services, Public Health Service, Centers for Disease Control and Prevention, National Institute for Occupational Safety and Health. (NIOSH) Publication No. 99-146. [ http://www.cdc.gov/niosh/docs/99-146/]

10. NFPA [2010]. NFPA 1620: Recommended practice for pre-incident planning, 2010 Edition. Quincy, MA: National Fire Protection Association.

11. International Fire Service Training Association (IFSTA) [2000]. Model Procedures Guide for Structural Firefighting. 2nd Edition. Stillwater, OK: Fire Protection Publications.

12. Delmar Publishers [2000]. Fire fighter's handbook: essentials of fire fighting and emergency response. New York: Delmar Thomson Learning.

13. NFPA [2012]. NFPA 1142: Standard on Water Supplies for Suburban and Rural Fire Fighting, 2012 Edition. National Fire Protection Association, Quincy, MA.

14. Klaene BJ and Sanders RE [2000]. Structural fire fighting. Quincy, MA: National Fire Protection Association.

15. NFPA [2007]. NFPA 1911, Standard for the Inspection, Maintenance, Testing, and Retirement of In-service Automotive Fire Apparatus, 2007 Edition. National Fire Protection Association, Quincy, MA.

16. NFPA [2009]. NFPA 1002: Standard for Apparatus Driver/Operator Professional Qualifications, 2009 Edition. National Fire Protection Association, Quincy, MA. 


\section{Volunteer Captain Dies After Floor Collapse Traps Him in Basement - New York}

17. NFPA [2008]. NFPA 1521. Standard for Fire Department Safety Officer. 2008 Edition. Quincy, MA: National Fire Protection Association.

18. NIOSH [2009]. Workplace solutions: preventing deaths and injuries of fire fighters working above fire-damaged floors. Cincinnati, OH: U.S. Department of Health and Human Services, Centers for Disease Control and Prevention, National Institute for Occupational Safety and Health, DHHS (NIOSH) Publication No. 2009-114 [http://www.cdc.gov/niosh/docs/wpsolutions/2009-114/default.html].

19. Corbin DE [2000]. Seeing is believing. Occupational Safety and Health 69(8):60-67.

20. Underwriters Laboratories [2009]. Structural stability of engineered lumber in fire conditions [http://www.ul.com/global/eng/pages/offerings/industries/buildingmaterials/fire/courses/structu ral/]. Date accessed: Aug 2013.

21. TriData Corporation [2003]. Current status, knowledge gaps, and research needs pertaining to fire fighter radio communication systems. Report prepared for NIOSH. Arlington, VA: TriData Corporation. http://www.cdc.gov/niosh/fire/RadComSy.html. Date accessed: Aug 2013.

22. USFA / IAFF [2008]. Voice Radio Communications Guide for the Fire Service. Joint publication by cooperative agreement with the International Association of Fire Fighters (IAFF) and the U.S. Fire Administration (USFA). October 2008. http://www.iaff.org/08News/PDF/RadioCommunications.pdf. Date accessed: April, 2014.

23. IAFC [2011]. Position Statement: Assignment of Portable Radios/Two-Way Communications Devices to Every Firefighter on the Fireground, dated May 7, 2009. International Association of Fire Chiefs. Fairfax, VA. http://www.iafc.org/associations/4685/files/IAFCposition_Daniels_PortableRadiosPositionStat ement.pdf. Date accessed: Aug 2013.

24. USFA [1999]. Special Report: Improving Firefighter Communications. U.S. Fire Administration / Technical Report Series: USFA-TR-099/January 1999. Department of Homeland Security, Emmitsburg, MD.

25. IAFF [2010]. IAFF Fire Ground Survival Program. International Association of Fire Fighters. http://www.iaff.org/HS/FGS/FGSIndex.htm. Date accessed: Aug 2013.

26. Christopher Brennan. Fire Service Warrior. Situational awareness, http://thefireservicewarrior.blogspot.com/2009/11/situational-awareness.html. Date accessed, March, 2014. 


\section{Volunteer Captain Dies After Floor Collapse Traps Him in Basement - New York}

27. Gasaway, R.B. (2013). Situational Awareness for Emergency Response. Tulsa, OK: PennWell.

28. Sendelbach TE [2004]. Managing the fireground Mayday: the critical link to firefighter survival http://www.firehouse.com/article/10541890/managing-the-fireground-mayday]. Date accessed: April, 2014.

29. IAFF [no date]. IAFF Fire Ground Survival Program. Washington, DC: International Association of Fire Fighters [http://www.iaff.org/HS/FGS/FGSIndex.htm]. Date accessed: Aug 2013.

30. Grossman D, Christensen L [2008)]. On combat: the psychology and physiology of deadly conflict in war and peace, 3rd ed. Millstadt, IL: Warrior Science Publications.

31. Clark BA [2005]. "Strategy and Tactics" - 500 Mayday called in rookie school http://www.firehouse.com/article/10498807/500-maydays-called-in-rookie-school. ]. Date accessed: Aug 2013.

32. U.S. Fire Administration [2006]. Mayday CD Q133 Firefighter safety: calling the Mayday and H134 Calling the Mayday: hands on training. Emmitsburg, MD: U.S. Department of Homeland Security, U.S. Fire Administration, National Fire Academy.

33. Clark BA [2008]. Leadership on the line: firefighter Mayday doctrine-where are we now? Radio@Firehouse.com http://www.firehouse.com/podcast/10459336/leadership-on-the-linefirefighter-mayday-doctrine-where-are-we-now. ]. Date accessed: Aug 2013.

34. IAFC Safety, Health, and Survival Section [2010]. Rules of engagement of structural firefighting [http://www.iafcsafety.org/image/ROE_Poster.pdf. Date Accessed: April, 2014.

35. Bachrach A, Egstrom G [1987]. Stress and performance in diving. San Pedro, CA: Best Publishing.

36. International Association of Fire Chiefs [2009]. Rules of Engagement for Firefighter Survival. http://www.iafc.org/Operations/LegacyArticleDetail.cfm?ItemNumber=2718. Date Accessed: Aug 2013.

37. Dunn V (1988). Collapse of burning buildings, a guide to fireground safety. Saddle Brook, NJ: Fire Engineering Books and Videos, pp. 88-93. 


\section{Volunteer Captain Dies After Floor Collapse Traps Him in Basement - New York}

38. NFPA [2014]. NFPA 1720, standard for the organization and deployment of fire suppression operations, emergency medical operations, and special operations to the public by volunteer fire departments, 2014 Edition. Quincy, MA: National Fire Protection Association.

\section{Investigator Information}

This incident was investigated by Jay L. Tarley and Stephen Miles, Safety and Occupational Health Specialists, and Matt Bowyer, General Engineer, with the Fire Fighter Fatality Investigation and Prevention Program, Surveillance and Field Investigations Branch, Division of Safety Research, NIOSH located in Morgantown, WV. An expert technical review was provided by Chief Richard B. Gasaway. A technical review was also provided by the National Fire Protection Association, Public Fire Protection Division.

\section{Disclaimer}

Mention of any company or product does not constitute endorsement by the National Institute for Occupational Safety and Health (NIOSH). In addition, citations to Web sites external to NIOSH do not constitute NIOSH endorsement of the sponsoring organizations or their programs or products. Furthermore, NIOSH is not responsible for the content of these Web sites. 